\title{
New Zealand, 1934: III
}

From 'Address at Chateau', Dominion (Wellington), 4 April 1934, reprinted in What I Said in NZ, p. 10. The following extract is taken not from a formal interview, but from the report of a Sunday evening gathering of some 240 people at Chateau Tongariro, at which Shaw invited questions from the floor.

In answer to the question: 'What is your opinion of New Zealand as a tourist country?' Mr Shaw replied:

'I do not think it is going to be a tourist country. It is not as bad as that. New Zealand is a sort of place you should keep for the recreation of your own workers and people and not so much for tourists. The temptation is there because New Zealand has no money to waste.

'You have one advantage in your shows and sights. They are really very curious and interesting. In other parts of the world they have fake sights. People try to manufacture them and tell you something happened there that didn't. In New Zealand I have been taken to see a great many sights, and they are really interesting and extraordinary.

"That is the main thing. The danger is that, when people find out what an interesting place New Zealand is, they may come in crowds and you will be tempted to give up some interesting industry and become waiters (laughter) keeping hotels for tourists; and then when revolutions come in the countries where the tourists come from and they lose their money, where are you? I strongly advise you not to make too much of the tourist sights except for yourselves.'

\section{New Zealand, 1934: IV}

From 'The Dominion Interview', The Dominion (Wellington) 4 April 1934, reprinted in What I Said in NZ, p. 14. Although this substantial interview was presented as a live one, given by Shaw at Palmerston North after a long journey from Chateau Tongariro, it is classified as written in Dan H. Laurence's Bernard Shaw: A Bibliography, 2 vols (Oxford: Clarendon Press, 1983) vol. II, item C3046. 